\title{
Assessment of Adaptable Urban Environment for Public Art Integration via Observation Study
}

\author{
Muhammad Falihin Jasmi ${ }^{1}$, Nik Hanita Nik Mohamad ${ }^{2}$ \\ ${ }^{1}$ Institute of Graduate Studies, \\ Faculty of Architecture, Planning and Surveying, \\ Universiti Teknologi MARA (UiTM) Shah Alam, Selangor, Malaysia \\ ${ }^{2}$ Centre of Studies in Landscape Architecture, \\ Faculty of Architecture, Planning and Surveying, \\ Universiti Teknologi MARA (UiTM) Puncak Alam, Selangor, Malaysia \\ falihinjasmi@gmail.com
}

\begin{abstract}
In Malaysia, there is an unprecedented interest in public art, especially in the major cities. Notwithstanding the increasing interest, however, the rationale and placement of it is extensively debatable. Therefore, this paper aims to examine the adaptable urban environment for public art integration towards enhancing the image of Johor Bahru City Centre, through an observation study. It identifies the urban morphology that substantiates development of suitability plan for public art placement, whilst refining legibility, connectivity, and urban fabric. The outcome of this paper is hoped to support related professionals in defining guidelines and strategies for public art, towards liveable city.
\end{abstract}

Keywords: Public Art; Urban Environment; Adaptable Environment; Urban Morphology

eISSN 2398-4295 @ 2018. The Authors. Published for AMER ABRA cE-Bs by e-International Publishing House, Ltd., UK. This is an open-access article under the CC BY-NC-ND license (http://creativecommons.org/licenses/bync-nd/4.0/). Peer-review under responsibility of AMER (Association of Malaysian Environment-Behaviour Researchers), ABRA (Association of Behavioural Researchers on Asians) and cE-Bs (Centre for EnvironmentBehaviour Studies), Faculty of Architecture, Planning \& Surveying, Universiti Teknologi MARA, Malaysia. DOI: http://dx.doi.org/10.21834/ajbes.v3i13.141 


\subsection{Introduction}

Public art had evolved and established in a variety of forms and materials; from an integrated artwork on the building surface (mural and graffiti), free standing sculpture, statue, and monument, towards modern technology-integrated artwork such as digital display and vertical greenery. Instead of standing as a landmark in a city centre, series of public art could provide a visual sequence that improves connections between spaces, enhance the visual experience for the public and consequently help them to understand and memorize the legibility of the city. It contributes to an enhancement of public realm, successful place making and development of cultural and social capital (Australian Institute of Landscape Architecture, 2010). The public art's impact on the community is priceless, as it adds to the understanding of a place, its past, and current physical environment and cultural fabric (Nurul Izzah et.al, 2014). Additionally, public art boosts city economy and give benefits to the community. According to City of San Diego Commission for Arts and Culture (2004), a lively public art program has sustained economic strength and engrossed individuals and companies, which can promote and facilitate prosperity for the citizens.

In Malaysia, there is an unprecedented interest and excitement in public art, especially in the major cities of Kuala Lumpur, Georgetown, Ipoh, Shah Alam and Johor Bahru. Notwithstanding the increasing interest, however, the rationale, locality, and placement of public art in Malaysia are essential issues that need to be addressed, particularly in the realm of built environment. Cardiff County Council (2005) stated that public art should be placed in publicly accessible and visible spaces, which is open for public appreciation and interaction. Meanwhile, Irish Museum of Modern Art (2008) cited that the establishment of public art often responds to the public place and its specification; it's setting, current site activity, significance and history. Currently, public art in Malaysia are mostly installed to fill the empty and lost urban spaces which overturn the objective of public art as a public object (Flynn, 2013) thus leading to vandalism. Furthermore, several public art implemented at the chosen sites are placed just for the sake of beautification without responding to any narration of symbolism of history, celebration of an event or other humanistic factors. Therefore, this paper aims to examine the best adaptable urban environment for public art integration towards enhancing the image of Johor Bahru City Centre through an Observation study. The objectives of this paper are (a) to determine the characteristic and morphology of study area that significantly contributes to the integration of public art program and (b) to establish suitability plan for public art placement towards a liveable city.

\subsection{Case Study: Johor Bahru City Centre}

Johor Bahru City Centre is chosen as the study area for its strategic location at the southern entrance of Peninsular Malaysia (via land), which provides the first impression among both the international and local tourists (Figure 1). The primarily invaluable multicultural and prosperous history of Johor Bahru offers cultural significance for public art purposes. As provided in Iskandar Malaysia Johor Bahru City Centre Physical Planning Initiatives 2006 to 2025, Objective 10 stated; "Promoting public art that reflects the identity of a city and it is the voice of the local communities and helps to strengthen relationships between diverse groups." In this light, the paper will cover a detailed assessment of the character of Johor 
Bahru City Centre; it's social, cultural and environmental aspects that play a significant role in establishing an adaptable urban environment for public art integration.

(a)

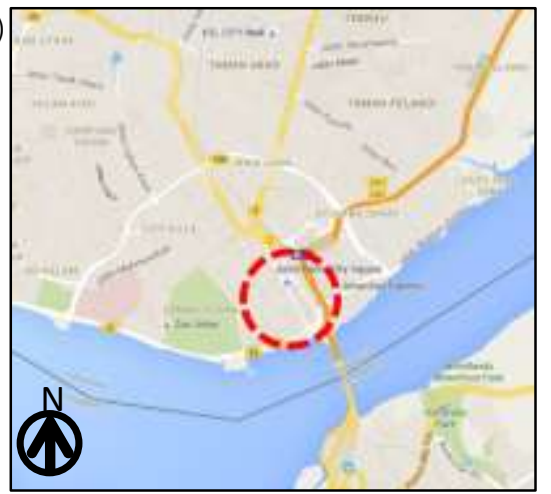

(b)

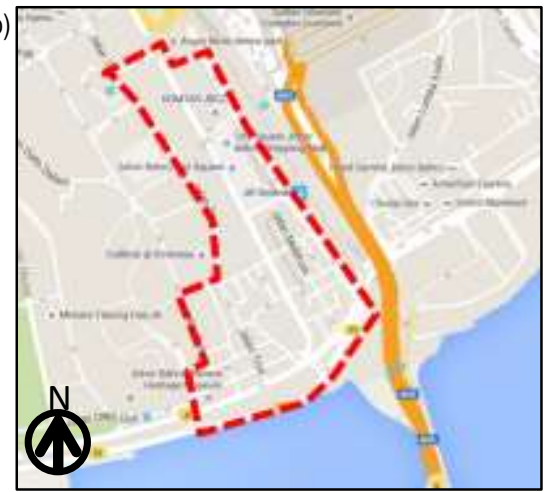

Figure 1: (a) Key Plan; (b) Location Plan of Study Area (Source: Google Maps,2016)

\section{0 Literature Review}

Presently, several local authorities in Malaysia had started to organize public art programs that encourage public participation. It is a respectable effort to educate and generate awareness among the society on public art. For instance, Dewan Bandaraya Kuala Lumpur (DBKL) had launch artwork and sculpture competition for public participation in 2014, which aims to improve Kuala Lumpur urban design image and way-finding. Additionally, Penang State Tourism and Development Office with the collaboration of Penang Global Tourism and appointed artist, Lithuanian-born artist, Ernest Zacharevic had produced a sequence of public art in Georgetown, Penang integrating a series of welded iron wall caricatures and mural painting (Figure 2).

(a)

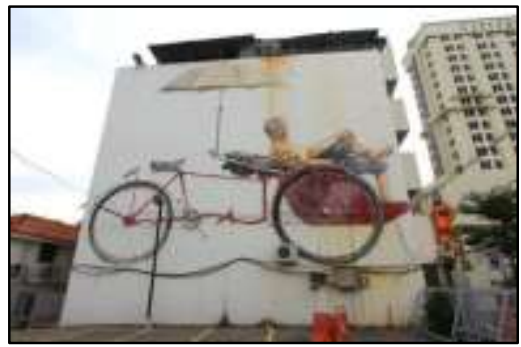

(b)

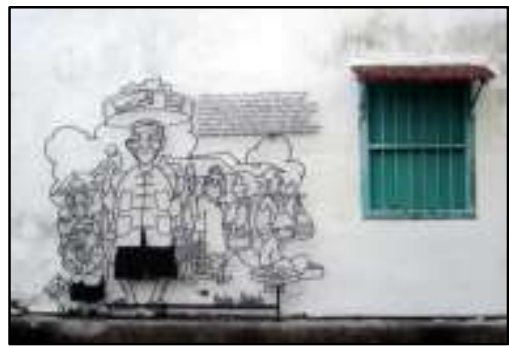

Figure 2: (a) Expressive Artworks, mural by Ernest Zacharevic; (b) Efficient Artworks, welded iron signage in Georgetown, Penang.

(Source: Google Images, 2016) 


\subsection{Imageability Study}

According to Lynch (1960), imageability is the quality of a physical object that delivers an observer an intense and vivid image while legibility is the easiest way for people to recognize the layout of a place. Besides that, a highly imaginable city would be well-formed, holds very distinct parts and would be immediately recognizable to the people (Erismis \& Gezerman, 2014). Both of them urged that a city grows not only its brand but also its image and desirability of the outer world. The Lynch's theory exerts massive influence, not only in urban design but also more broadly in social science and art history (Raynsford, 2011). There are five elements of legibility recognized; (i) Landmarks, (ii) Nodes, (iii) Districts, (iv) Paths and (v) Edges.

\subsection{Serial Vision Study}

Serial vision happens when a person walks through a town at a uniform speed, and a series of images will reveal (Cullen, 1961). The notion of serial vision is a sequence of static viewpoint frames that positioned in accord with the plan (Blizard \& Fish, 2013).This exercise concerns on the optic, which leads a human movement in a city. Besides, the place and its contents can be renowned during the Serial Vision study. The place can be recognized throughout response to the human's position in the environment while contents can be determined through examination of the fabrics of town such as colour, texture, scale, style, character, personality and distinctiveness (Wessel et.al, 2008).

\subsection{Methodology}

The fieldwork observation to identify the urban morphology of Johor Bahru is conducted within the boundary of Johor Bahru City Centre covering an area of 78.4 acres. It encompassed (i) land uses and activities, (ii) solids, voids, building form and massing, (iii) Imageability study and (iv) Serial Vision study. The rationale of site observation is to determine the existing urban fabric of the study area especially the spirit of the place (genus loci). Observation study was conducted from May 2015 to June 2015 by one observer (the writer). The observation was unanimously held during weekdays and weekend, days (8am to 10 am and $4 \mathrm{pm}$ to $6 \mathrm{pm}$ ) and nights ( $8 \mathrm{pm}$ to $10 \mathrm{pm}$ ) as to understand and clearly identify the trend and patterns of the human activities and interactions with their surroundings. Tools used during this exercise were a camera (to snap photos of site scenery) base plan of Johor Bahru City Centre (to trace the accurate location of character and urban fabric on the map) and stationeries.

The land use in Johor Bahru City Centre is occupied by commercial and trading activity (Figure 3a). There are commercial areas being dominated by specific races. Firstly, Chinese commercial area can be found along Jalan Tan Hiok Nee while Indian commercial area is dominant along Jalan Trus and Jalan Ungku Puan. Additionally, there is a river named Sungai Segget across the study area. Previously, it was the nerve of the city and currently under rehabilitation process for a better urban environment accordingly to the Johor Transformation project. This study area is strategically located, which is near Gerbang Selatan Bersepadu (Southern Integrated Gateway) that incorporating the city's main railway station, JB Sentral, 
and customs, immigration, and quarantine complex (CIQ).

(a)

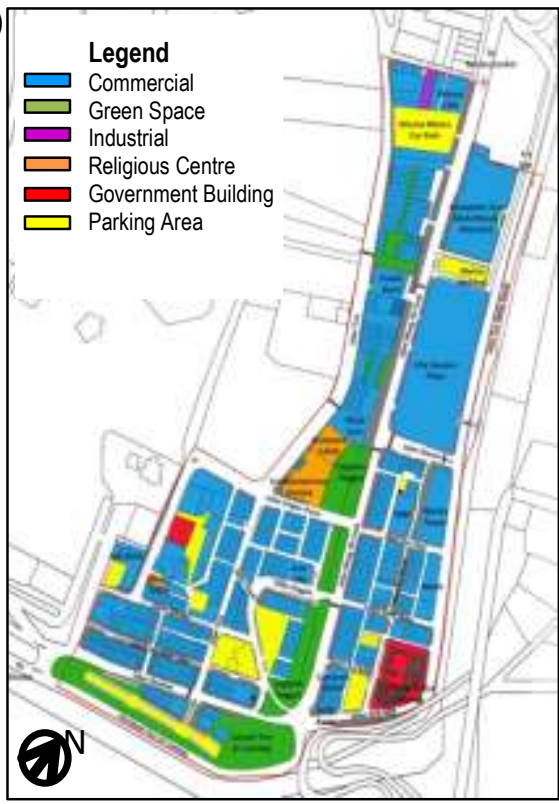

(c)

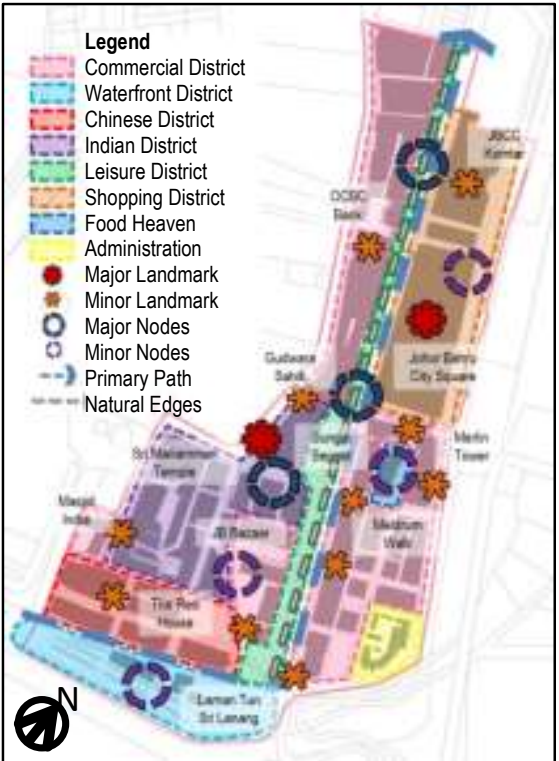

(b)

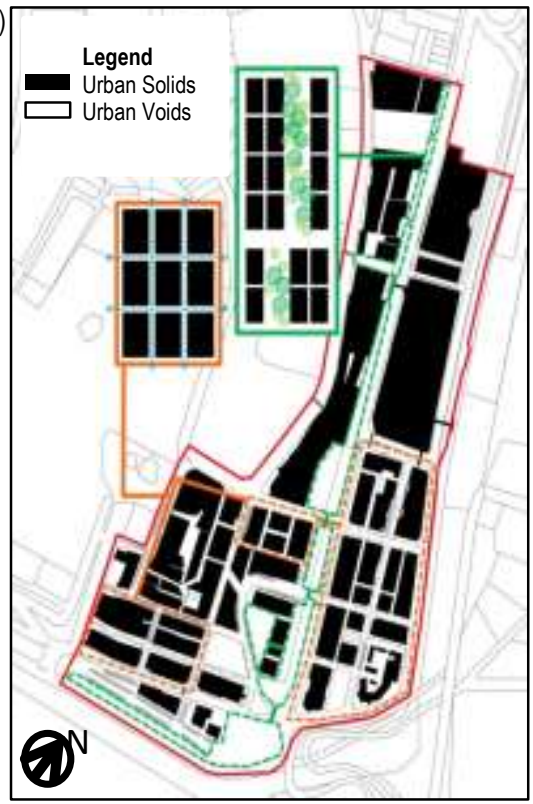

(d)

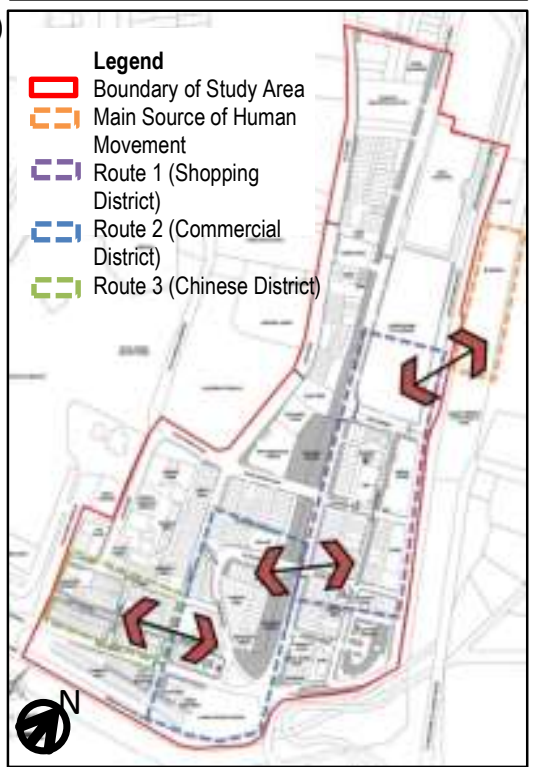

Figure 3: (a) Land Use map; (b) Urban Solids and Voids map; (c) Imageability map; (d) Serial Vision map of Johor Bahru City Centre. 
The typological pattern of solids in Johor Bahru is dominated by grid pattern covering commercial shop houses area (Figure $3 \mathrm{~b}$ ). This grid pattern increases the permeability in Johor Bahru City Centre and easier people access. Urban voids such as Laman Tun Sri Lanang and Legaran Segget provide contrast to the solid urban environment. The different styles of buildings show the evolution of Johor Bahru over the years and become one of the uniqueness of Johor Bahru. There are also public monuments which stand-alone with distinctive features such as Sri Mariamman Temple, Gurdwara Sahib, and Masjid India.

Five elements of legibility were identified in the study area for the Imageability study. Photographs of each element in the study area were taken and sited on the map to produce an Imageability map of Johor Bahru City Centre (Figure 3c). Additionally, any cultural and heritage values of the element were acknowledged, and it will become a reference to commemorate the history and culture of Johor Bahru City Centre through public art design (Figure 4).

(a)

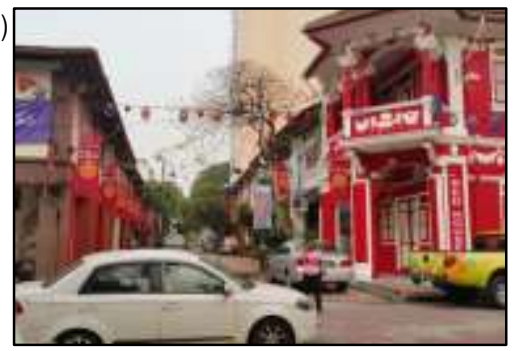

(b)

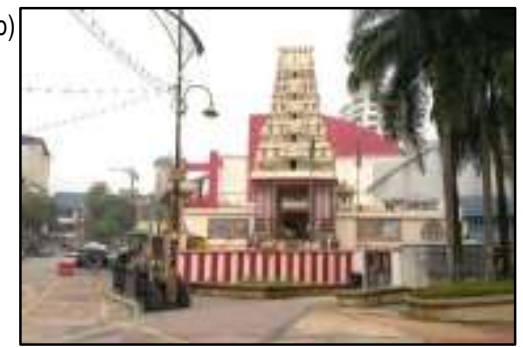

Figure 4: (a) Land Use map of Johor Bahru City Centre; (b) Urban Solids and Voids map of Johor Bahru City Centre.

(Source: Author's archive)

For the Serial Vision study, there are three routes selected from the research area. The routes were selected from the districts identified in Imageability Study; (i) Shopping District, (ii) Commercial District and (iii) Chinese District (Figure 3d). The origins of each route are the source of human movement towards the destination in the study area. The rationale for selecting these routes from three different districts is each of them have a potential to be linked to each other from the main source of human movement (located beside the site boundary), Gerbang Selatan Bersepadu and JB Sentral. As well, the distance of each route is within walkable distance; connecting pedestrian towards varied destinations within a reasonable amount of time and effort, and offering visual interest during the journeys (Southworth, 2005). It will also lead towards any identification of comparison of feeling between the routes chosen. A series of images is taken based on the visual cues that generate human movement from one spot to another spot. The serial images are taken on the eye level, and the visual cues are influenced by the observer's sight. Walking distance for each route is approximately 500 metre (walkable for pedestrian experience). The contents of a place along the routes were perceived as to determine the characteristic or the urban fabric of the town. 


\subsection{Results and Discussions}

All the data obtained from observation study are discussed (solely on the writer's judgement as observer) to define the advantages and disadvantages, followed by the synthesis of issues, concerns and opportunities accordingly to the indicators and being adapted into synthesis map to highlight precise location as the essential information for public art incorporation. Table 1 summarized all the main indicators data from the observation study that response to the objective (a) which to determine the characteristic and morphology of study area that significantly contributes to the integration of public art program.

Table 1: Summary of main indicators from observation study.

\begin{tabular}{|c|c|c|c|c|}
\hline Indicatorn & (1) Land uses and activities & $\begin{array}{l}\text { (ii) Solids, voids, bullding } \\
\text { form and massing }\end{array}$ & (iii) Imageabilify Study & (iv) Serial vision study \\
\hline 1. Advantages & $\begin{array}{l}\text { a stongh characteraed by } \\
\text { fe diverse races' commercal } \\
\text { and trading } \\
\text { b. Lively by pedestian } \\
\text { activies }\end{array}$ & 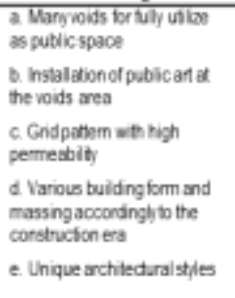 & 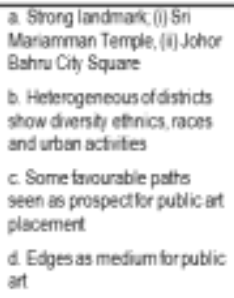 & $\begin{array}{l}\text { a Every place has is } \\
\text { own characherfnof } \\
\text { showcasesthe at and } \\
\text { colural values }\end{array}$ \\
\hline 2 Disadvartages & $\begin{array}{l}\text { a Less uflibed of pubicspace } \\
\text { b Ample parting lots }\end{array}$ & $\begin{array}{l}\text { a. Voids becomes solisied } \\
\text { spoce because of poor } \\
\text { cornectrity } \\
\text { b. Some building façade } \\
\text { createmonctonous impat }\end{array}$ & $\begin{array}{l}\text { a. Less utiled of minor } \\
\text { modes: Laman Tun Sn Lanang } \\
\text { b. Few aspects of legbityin } \\
\text { Johor Bahru Cty Cerbe are } \\
\text { poor }\end{array}$ & $\begin{array}{l}\text { a Poorip mantained of } \\
\text { some contents because } \\
\text { imesponsible humsn } \\
\text { behsiour } \\
\text { b. Lack of clearvisal } \\
\text { caes }\end{array}$ \\
\hline 3. losues & $\begin{array}{l}\text { a. Poorinkages or } \\
\text { connectivity results poor } \\
\text { uniced of certain public } \\
\text { spaces }\end{array}$ & 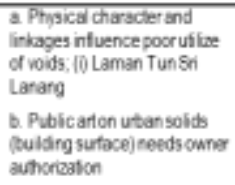 & $\begin{array}{l}\text { a. Poor magesbity that } \\
\text { degicts he diersib and } \\
\text { identy of bhor Bahs } \\
\text { b. Legibiliy elements are not } \\
\text { efective enough }\end{array}$ & $\begin{array}{l}\text { a. Mood or keing of } \\
\text { observer depends on; } \\
\text { (0) visual cues and 0iv } \\
\text { conlerts in a place }\end{array}$ \\
\hline 4. Concems & $\begin{array}{l}\text { a. Actwbes that make the chy } \\
\text { hely needto be mairtained } \\
\text { boards atractng more } \\
\text { ishors; (0) } \sqrt{8} \text { Baeas, (i) Food } \\
\text { Heaven area }\end{array}$ & $\begin{array}{l}\text { a. Presendion ol henlage } \\
\text { bulding hat presentlocal } \\
\text { distnctieness; ( I Tradiona } \\
\text { Chinese Shop Houses, (i) Sri } \\
\text { Mariamman Temple }\end{array}$ & $\begin{array}{l}\text { a. Preservalion ol existing } \\
\text { landmarks had nepresert } \\
\text { nespectwe dsticts and act as } \\
\text { noule marker } \\
\text { b. Erhancementof several } \\
\text { puths to dinecthuman } \\
\text { movemert }\end{array}$ & $\begin{array}{l}\text { a. Vantiy of conlents } \\
\text { eshance he sense of } \\
\text { place } \\
\text { b. Conlants of a place } \\
\text { needto be considered } \\
\text { as a guide or inspiraton } \\
\text { to design publicat }\end{array}$ \\
\hline 5. Opportunibies & 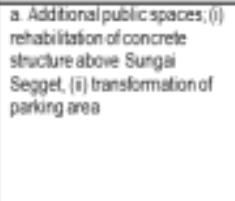 & 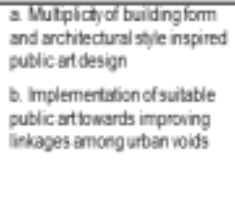 & $\begin{array}{l}\text { a. Roles of pubic art to } \\
\text { enhance the image of the chy } \\
\text { b. Integrating pubicicat in } \\
\text { majornodes, favouratie paths } \\
\text { and tagmentaryedges }\end{array}$ & 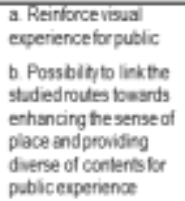 \\
\hline 6. Synthesis & $\begin{array}{l}\text { a Spsces that need to be } \\
\text { connected } \\
\text { b. Spaces that need to be } \\
\text { mairtained } \\
\text { c. Spaces hat need to be } \\
\text { tanslomed. }\end{array}$ & $\begin{array}{l}\text { a Voids with high potenisal b } \\
\text { be designed } \\
\text { b. Solids with high hertage } \\
\text { and anchilectural value }\end{array}$ & $\begin{array}{l}\text { a. Nodes for public art } \\
\text { plscemert } \\
\text { b. Landmarks fratneed to be } \\
\text { emtossed } \\
\text { c. Dotricts with strong } \\
\text { character } \\
\text { d. Fancurable pat } \\
\text { e. Nalural edpes under } \\
\text { rehabilation }\end{array}$ & $\begin{array}{l}\text { a. Feeingoferien } \\
\text { rodes } \\
\text { b. Potertial putic art } \\
\text { trail }\end{array}$ \\
\hline
\end{tabular}


Overlay technique is used to determine the suitability of an area for public art placement. This technique is one of the processes to produce suitability map towards a liveable city (objective b). All the synthesis maps from each indicator were used in the overlay technique to generate the final composite map (Figure 5). The suitability plan identifies the potential areas for development, potential areas for public art placement and trail for public art from the Serial Vision study (Figure 6). Evidently, the final suitability plan attempt to summarize all of the existing site and contextual condition that could substantially influence the spatial organization and strategic location for public art in Johor Bahru City Centre (Table 2).

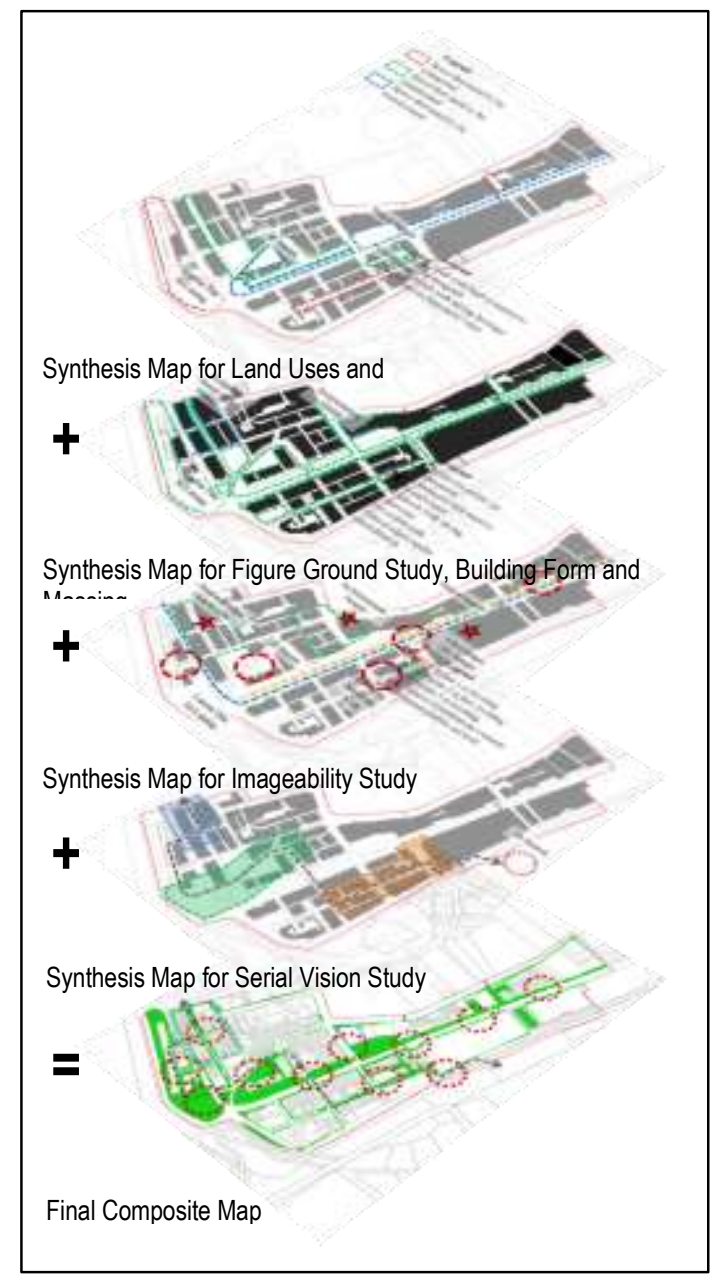

Figure 5: Overlaying technique to form Final Composite Map 


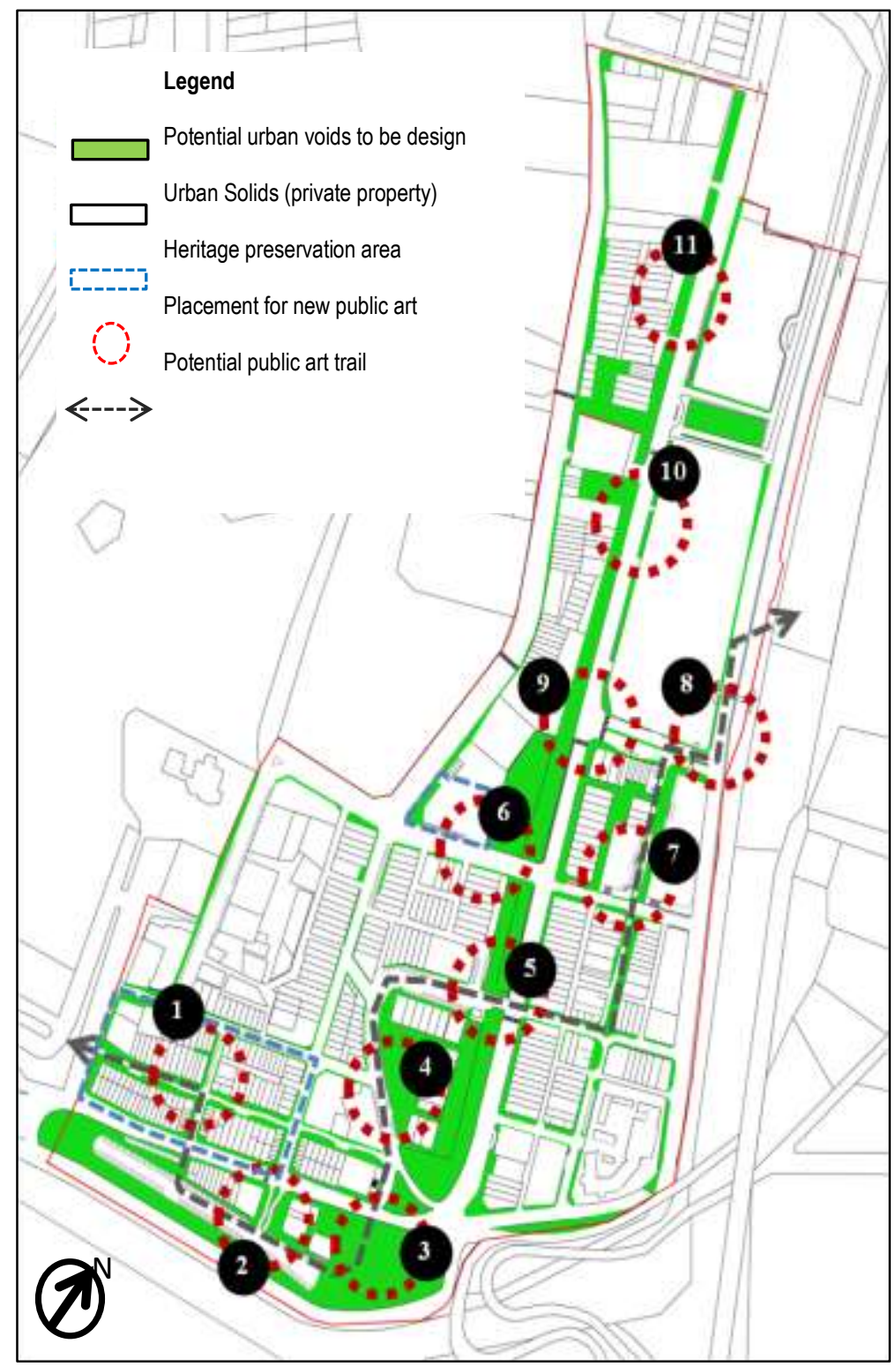

Figure 6: Final Suitability Plan for public art placement in Johor Bahru City Centre 


\section{Table 2: Summary of main indicators from observation study.}

\begin{tabular}{|c|c|}
\hline Indicators & Descriptions \\
\hline $\begin{array}{l}\text { a. Potential urban } \\
\text { voids to be design }\end{array}$ & 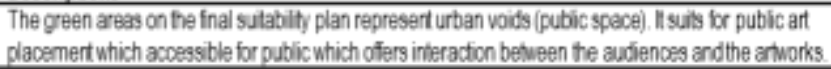 \\
\hline $\begin{array}{l}\text { b. Urban solids } \\
\text { (private property }\end{array}$ & 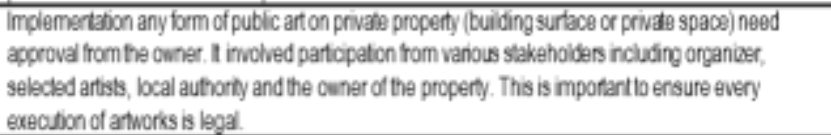 \\
\hline $\begin{array}{l}\text { c. Heritage } \\
\text { preservation area }\end{array}$ & 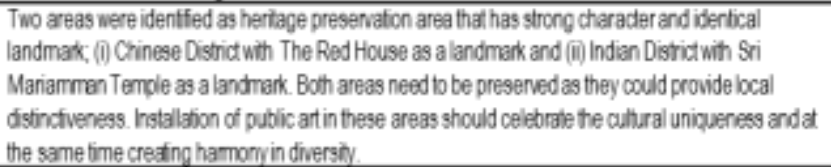 \\
\hline \multirow[t]{12}{*}{$\begin{array}{l}\text { d. Placement for } \\
\text { new public art }\end{array}$} & $\begin{array}{l}\text { Several appropriate public spacos were recognized to locale public art in the chy centre and those } \\
\text { atworks need to sul tis surrounding. There are as blow. }\end{array}$ \\
\hline & $\begin{array}{l}\text { 1. Chinese District Boost the sense of place and rejoice the Chinese culure and hertage that can } \\
\text { serve public whth addibonal knowledge. }\end{array}$ \\
\hline & $\begin{array}{l}\text { 2. Waterfort District Placemerts series of public art wil drectmore pubic b ufize Lamen Tun Sri } \\
\text { Lanarg. The anwork can commenorde the transformation of Johor Bahrufrom a fishing vilage into a } \\
\text { thriving chy centre. }\end{array}$ \\
\hline & $\begin{array}{l}\text { 3. Waterfort Distict Laman Tun Sri Lanarg needs visual cues hat can generale pubic b get there } \\
\text { and make the area liveler. }\end{array}$ \\
\hline & 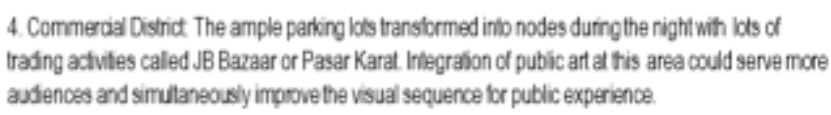 \\
\hline & 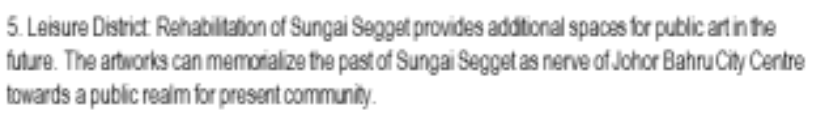 \\
\hline & $\begin{array}{l}\text { 6. hdian Distict Strong charader of indian cuture should be maintainod and any artworks execute at } \\
\text { this area should refects the indan hertage and enhanoe the ambiance. }\end{array}$ \\
\hline & $\begin{array}{l}\text { 7. Commercial District and Food Heaven District The existing contents of place need supervision by } \\
\text { local athority to ensure ts sustainabiity. Addtonal arworks should help to develop the amosphere of } \\
\text { food haaven area and more pedestrian friendy. }\end{array}$ \\
\hline & 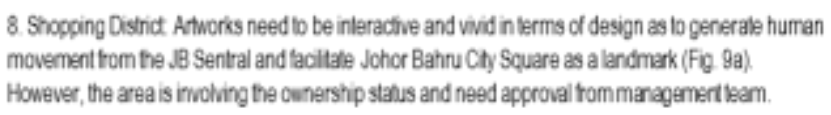 \\
\hline & 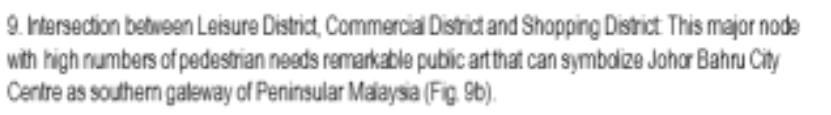 \\
\hline & $\begin{array}{l}\text { 10. Shopging District The main entranoe of Johor Bahru Ciy Square should be one of a best place to } \\
\text { locate commurity atwork as it being wilzed daly by the public. }\end{array}$ \\
\hline & $\begin{array}{l}\text { 11. Leisure District. Placement a series of public artin this area has potential for another putlic art trail } \\
\text { once the rehabiltafon process of Sungai Segget fnished. }\end{array}$ \\
\hline $\begin{array}{l}\text { e. Potential public } \\
\text { art trail }\end{array}$ & 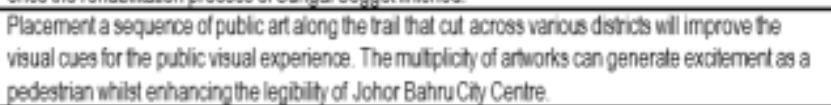 \\
\hline
\end{tabular}


(a)

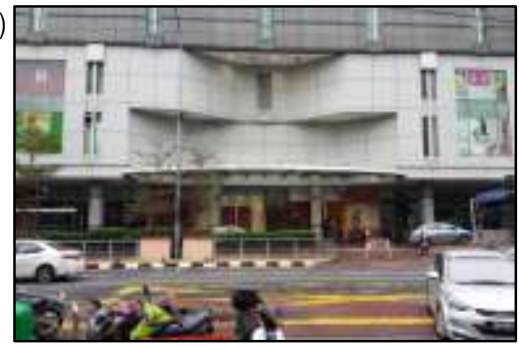

(b)

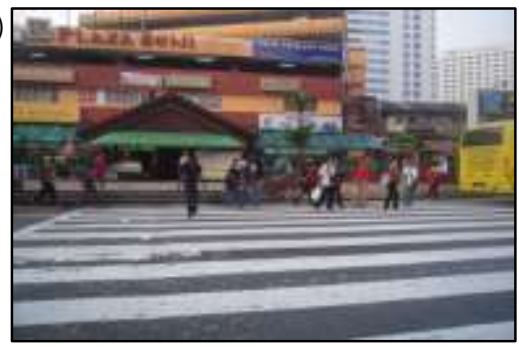

Figure 7: Potential area for public art placement, (a) Johor Bahru City Centre; (b) Intersection between Leisure District, Commercial District and Shopping District (Source: Author's archive)

\subsection{Conclusion}

The findings from Observation study indicated public art seems to hold a good prospective in Johor Bahru City Centre based on the characteristic and morphology of contemporary urban environment. Placement of public art at the suitable location has a possibility to create a liveable city and enhance the image of the city itself. All the indicators identified during the exercise; (i) land uses and activities, (ii) solids, voids, building form and massing, (iii) Imageability study and (iv) Serial Vision study, have affirmative results that tend to integrate public art as design solutions. This scenario will lead to the deliberation of design guidelines for public art as it could provide comprehensible practice for all projects. Plenty of private spaces and building façades have potential as medium to incorporate public art.

Notwithstanding the fact that few legibility elements are poor and not effective enough to symbolize the identity of Johor Bahru City Centre, contrariwise there are sufficient areas that have the opportunity to improve the imageability. Public art placements at nodes and along favourable paths have potential to generate interaction between the public and the artworks. Rehabilitation of natural edges (Sungai Segget) that will be partially covered with concrete slab provides ample space for the public realm. Further study after the project finished is needed as it has a possibility for public art locality. The heterogeneous nature of districts has the advantage to propose assorted types of artworks. It will show the interesting and colourful diversity of various ethnicity, races, and urban activities, contained within a city demarcation according to the era. Consequently, the sense of place could be enhanced and simultaneously provide multidimensional visual experience for the public.

Regarding visual sequence, some of the routes studied needs improvement and had a probability becoming a public art trail which links those three routes that cut across a variety of districts. Implementation of suitable artwork on the particular spot could enhance the visual cues and feel, and consequently, divert more public to experience the city as a pedestrian. Thus, a proper guideline for public art is needed as it could succour the planning, installation, and maintenance of the artworks in a city centre.

Through this, the suitable placement of artworks by utilization of urban design knowledge (production of suitability plan using overlaying technique) particularly on the efforts of 
assessing the adaptable environment could be addressed to improve the imageability and the city growth. The applied perceptive on the public art contribution and urban morphology could provide comprehensive information to the multi-disciplinary professionals primarily to determine appropriate artwork to be integrated into the urban area towards a better environment in a creative manner. Ultimately, participation from all stakeholders is essential to ensure the integration of public art benefits the city and the community for the present and future generations. Future research on public art should investigate the characteristic and morphology of other cities in Malaysia towards identifying any contrast of existing urban spaces; it's social, cultural and environmental aspects.

\section{References}

Australian Institute of Landscape Architecture (2010). Public Art and Landscape. National Policy Statement. Page 1

Blizard, M. \& Fish, C. (2013). An Archaeology of the Street: Analysis of Place in Urbino, Italy. Enquiry / Volume 10 Issue $12013,29-42$

Cardiff Country Council (2005). Cardiff Public Art Strategy. Cardiff Public Art Agency. Page: 17

City of San Diego Commission for Arts and Culture (2004). Public Art Master Plan. City of San Diego. Page 8

Cullen, G. (1961). The Concise Townscape. Taylor \& Francis. Page 2-4,10

Erismis, M. C, Gezerman, A. O. (2014). Analysis of Kadikoy Seashore from the Perspective of Lynch. International Journal of Modern Social Sciences. 2014, 3(2): 75-97

Flynn, B. (2013). City Centre Public Art Plan. City of Sydney Council. Page 5

Irish Museum of Modern Art (2008). What is Public Art?. Irish Museum of Modern Art (IMMA). Page 4

Lynch, K. (1960). Image of the City. Legibility and Imageability. MIT Press Page 4,6-9,10,12

Mohd Fabian, H. (2010). Towards Integrating Public Art in Malaysian Urban Landscape. Pertanika J. Soc. Sci. \& Hum. Page: 251-264

Muhizam, M. (2008). Public Art in the Federal Territory of Putrajaya: Questions of Value and Role. Wacana Seni Journal of Arts Discourse. Jil./Nol.8. Page: 2

Nurul Izzah, A. B., Mazlina, M. \& Nor Zalina, H. (2014) Vertical Greenery System as Public Art? Possibilities and Challenges in Malaysian Urban Context. Procedia - Social and Behavioral Sciences. Volume 153, 16 October 2014, Pages 230-241

Pullaro, C. (2013). Public Art Master Plan, City of John Creek, Georgia. Leadership John Creek. Page 6-7

Raynsford, A. (2011). Civic Art in an Age of Cultural Relativism: The Aesthetic Origins of Kevin Lynch's Image of the City. Journal of Urban Design, February 2011, Vol. 16. No. 1, 43-65

Southern Johor Economic Region (SJER). (2006). Comprehensive Development Plan 2006-2025. Part 3 Physical Planning Initiatives. Page 13-7 
Southworth, M. (2005). "Designing the Walkable City." J. Urban Plann. Dev., 10.1061/(ASCE)07339488(2005)131:4(246), 246-257.

Tyler, J. (2013) Public Art Master Plan, City of Coronado. Cultural Arts Commission. Page 6, 9

Wessel, G., Sauda, E. \& Chang R. (2008) Urban Visualization: Urban Design and Computer Visualization. CAADRIA 2008 (Proceedings of the 13th International Conference on Computer Aided Architectural Design Research in Asia) Chiang Mai (Thailand) 9-12 April 2008. Page 409-416 